\title{
Congenital adrenal hyperplasia in Surabaya: retrospective analysis of paediatric endocrinology private practice (1997-2011)
}

\author{
Connie Untario
}

\author{
From 7th APPES Biennial Scientific Meeting \\ Nusa Dua, Bali. 14-17 November 2012
}

Congenital Adrenal Hyperplasia $(\mathrm{CAH})$ is a hereditary disorder that can cause a huge impact to the sufferer, his family and surrounding living environment but is still often diagnosed late. We believe that a better understanding of the disease through analysis of the chief complaints and early signs of $\mathrm{CAH}$ will aid early diagnosis.

Analysis of chief complaints and early signs of $\mathrm{CAH}$ from paediatric endocrinology private practice (19972011) consisting of 10 females and 9 males was carried out. All CAH patients are referrals from other paediatricians in East Java.

Ambiguous genitalia was found in all females (10), 6 came with this as the chief complaint. Hyperpigmentation was never mentioned as a chief complaint although it is present in all patients except 3 males. One male patient came with precocious puberty. Diarrhoea and vomiting between male and female patients were equally distributed (6:5). Vomiting and diarrhoea was found in all salt wasting type boys (6) as the chief complaint. Only 1 out of 5 girls had vomiting and diarrhoea as the chief complaint. Failure to thrive was found as the chief complaint in 2 out of 7 patients with the condition. Family history was useful in the diagnosis of three patients. There were 12 patients diagnosed under 1 month, the other 7 patients were diagnosed between age 2 months and 10 years 7 months.

Careful examination of signs \& symptoms and high suspicion are needed to diagnose CAH. Ambiguous genitalia in females, hyperpigmentation, vomiting and diarrhoea, as well as failure to thrive are important clinical findings. In patients with precocious puberty, $\mathrm{CAH}$ should be considered in the differential diagnoses. Blood $\mathrm{Na}$ and $\mathrm{K}$ values are very useful in areas where hormonal exam is not available to help diagnose and to start electrolyte

Paediatric Department MitraKeluarga Surabaya Hospital, Indonesia therapy in salt wasting type. With early diagnosis, we can prevent the negative impact of the disease such as adrenal crisis, severe electrolyte imbalance, failure to thrive, precocious puberty and heavy psychological impact due to incorrect gender assignation.

Published: 3 October 2013

doi:10.1186/1687-9856-2013-S1-P125

Cite this article as: Untario: Congenital adrenal hyperplasia in Surabaya: retrospective analysis of paediatric endocrinology private practice (1997-2011). International Journal of Pediatric Endocrinology 2013 2013(Suppl 1):P125.
Submit your next manuscript to BioMed Central and take full advantage of:

- Convenient online submission

- Thorough peer review

- No space constraints or color figure charges

- Immediate publication on acceptance

- Inclusion in PubMed, CAS, Scopus and Google Scholar

- Research which is freely available for redistribution
() Biomed Central
() 2013 Untario; licensee BioMed Central Ltd. This is an Open Access article distributed under the terms of the Creative Commons Attribution License (http://creativecommons.org/licenses/by/2.0), which permits unrestricted use, distribution, and reproduction in any medium, provided the original work is properly cited. 